University of Nebraska - Lincoln

DigitalCommons@University of Nebraska - Lincoln

USDA National Wildlife Research Center - Staff Publications
U.S. Department of Agriculture: Animal and Plant Health Inspection Service

February 2004

\title{
Microsatellite Variation in Red-Winged Blackbirds (Agelaius phoeniceus)
}

C. Lenney Williams

USDA, Wildlife Services, National Wildlife Research Center

H.J. Homan

USDA, Wildlife Services, National Wildlife Research Center

J.J. Johnston

USDA, Wildlife Services, National Wildlife Research Center

G. M. Linz

USDA/APHIS/WS National Wildlife Research Center, george.m.linz@aphis.usda.gov

Follow this and additional works at: https://digitalcommons.unl.edu/icwdm_usdanwrc

Part of the Environmental Sciences Commons

Williams, C. Lenney; Homan, H.J.; Johnston, J.J.; and Linz, G. M., "Microsatellite Variation in Red-Winged Blackbirds (Agelaius phoeniceus)" (2004). USDA National Wildlife Research Center - Staff Publications. 398.

https://digitalcommons.unl.edu/icwdm_usdanwrc/398

This Article is brought to you for free and open access by the U.S. Department of Agriculture: Animal and Plant Health Inspection Service at DigitalCommons@University of Nebraska - Lincoln. It has been accepted for inclusion in USDA National Wildlife Research Center - Staff Publications by an authorized administrator of DigitalCommons@University of Nebraska - Lincoln. 


\title{
Microsatellite Variation in Red-Winged Blackbirds (Agelaius phoeniceus)
}

\author{
C. Lenney Williams, ${ }^{1,3}$ H. J. Homan, ${ }^{2}$ J. J. Johnston, ${ }^{1}$ and G. M. Linz ${ }^{2}$ \\ Received 10 October 2002-Final 19 February 2003
}

Territorial male red-winged blackbirds from five locations in the United States and Canada were genotyped using a suite of six microsatellite loci. Each population possessed unique alleles, but numbers of alleles per locus (range $=7.3-8.8$ ) and expected multilocus heterozygosities (range $=0.76-0.80$ ) were similar in all populations. Significant overall allele frequency differences were detected between some population pairs, and some pairwise $F_{\mathrm{st}}$ values were significant (but small). However, $F_{\mathrm{st}}$ among populations, although significant, was also small (0.009). Despite revealing low levels of population structure, the high multilocus polymorphism indicates these loci will be valuable in the genetic analysis of behavior and reproductive strategies in this species.

KEY WORDS: red-winged blackbird; microsatellite; Agelaius phoeniceus.

\section{INTRODUCTION}

Red-winged blackbirds (Agelaius phoeniceus) are abundant across North America and capable of long-distance movements. However, they also exhibit breeding site fidelity (Dolbeer, 1978), and show morphological (James et al., 1984; Linz et al., 1993) and vocalization differences (Kroodsma and James, 1994) on a regional geographical scale. Allozymes have revealed high levels of variation within redwinged blackbird populations and little genetic differentiation among them except

\footnotetext{
${ }^{1}$ USDA, Wildlife Services, National Wildlife Research Center, 4101 LaPorte Ave Fort Collins, Colorado 80521.

${ }^{2}$ USDA, Wildlife Services, National Wildlife Research Center, Great Plains Field Station, Bismarck, North Dakota.

${ }^{3}$ To whom correspondence should be addressed; e-mail: christen.1.williams@usda.gov.
} 
for large genetic differences between populations in California and those across the rest of the United States (Gavin et al., 1991). Ball et al. (1988) detected "mild" mitochondrial DNA structure among red-winged blackbird populations from 14 U.S. states, as well as one Canadian province and two Mexican states.

Given the greater rate of evolution at microsatellite loci, they may be informative enough to detect population structure in species that lack allozyme structure. Furthermore, male red-winged blackbirds are territorial and exhibit site fidelity (reviewed in James et al., 1984), so biparentally inherited markers may reveal population structure not detected using maternally inherited mitochondrial markers. In many other species, microsatellite data are useful for estimating population differentiation, gene flow, and kinship. If sufficient differences are detected in microsatellite allele frequencies, unknown individuals can be assigned to most likely source populations.

Red-winged blackbirds can cause locally severe damage to agricultural crops (Linz et al., 2000), with estimates of sunflower damage in the northern Great Plains of North America exceeding U.S. \$2,000,000 annually (Peer et al., 2003). Genetic markers to study relationships among regional or finer scale populations would be useful for developing management tools for this species. Our goal was to identify polymorphic microsatellite loci in red-winged blackbirds, and determine levels of variation within and among five populations sampled across North America. To our knowledge this is the first report of microsatellite variation among red-winged blackbird populations.

\section{MATERIALS AND METHODS}

We identified 10 potentially useful microsatellite loci from the literature: 7 that had been developed in great-tailed grackles (Quiscalus mexicanus-Hughes et al., 1998) and 3 in brown-headed cowbirds (Molothrus ater-Gibbs et al., 1997). Muscle or blood was taken from 95 territorial male red-winged blackbirds collected in two Canadian provinces (Alberta and Manitoba), and three states in the United States (California, Louisiana, and Minnesota) in June and July 2001 (Table I).

Table I. Red-Winged Blackbird Samples Used in This Study

\begin{tabular}{llll}
\hline Population & Collection dates & $n$ & \multicolumn{1}{c}{ Subspecies } \\
\hline California & July 2001 & 19 & A.p. phoeniceus \\
Louisiana & July 5, 2001 & 20 & A.p. littoralis \\
Alberta & June 29,2001 & 23 & A.p. phoeniceus \\
Minnesota & June 6-11, 2001 & 16 & A.p. phoeniceus \\
Manitoba & June 19,2001 & 16 & A.p. phoeniceus \\
\hline
\end{tabular}


DNA was isolated from muscle by using a Qiagen tissue kit (Valencia, CA) and the manufacturer's protocol. A drop of blood was placed in lysis buffer (Longmire et al., 1988), which was stored and shipped at room temperature, then frozen at $-20^{\circ} \mathrm{C}$. An aliquot was digested with Proteinase $\mathrm{K}$ at $55^{\circ} \mathrm{C}$ for $3 \mathrm{~h}$. Proteins were precipitated by addition of $\mathrm{NaCl}$ and removed by centrifugation. DNA was precipitated with ethanol, collected by centrifugation, rehydrated in TE, reprecipitated, and quantified by fluorimetry.

All 10 loci were screened in red-winged blackbirds. Ten-microliter screening amplifications included $200 \mu \mathrm{M}$ dNTPs (Promega, Madison, WI), $0.5 \mu \mathrm{M}$ primers, 0.5 U Taq polymerase (Promega, Madison, WI), $1 \times$ buffer, $100 \mathrm{ng}$ template DNA, $1.5 \mathrm{mM} \mathrm{MgCl}_{2}$, as well as $0.1 \mu \mathrm{L}$ of fluorescent dNTPs (Applied Biosystems, Foster City, CA). Locus-specific annealing temperatures ranged from 50 to $58^{\circ} \mathrm{C}$ and were determined empirically. Cycling parameters were $94^{\circ} \mathrm{C}$ for $2 \mathrm{~min}$, then 35 cycles of $94^{\circ} \mathrm{C}$ for $30 \mathrm{~s}$; locus-specific annealing temperature for $30 \mathrm{~s}, 72^{\circ} \mathrm{C}$ for $30 \mathrm{~s}$, and a final extension step of $72^{\circ} \mathrm{C}$ for $2 \mathrm{~min}$. Amplification products were held at $4^{\circ} \mathrm{C}$ or $-20^{\circ} \mathrm{C}$ until they were electrophoresed on $6 \%$ Long Ranger gels (BMA, Rockland, ME) using a fluorescent internal size standard (400HD; Applied Biosystems, Foster City, CA) on an ABI Prism 377 (Applied Biosystems, Foster City, CA). Six microsatellite loci (Mau10, Mau20, Mau23, Qm10, Qm21, and Qm37) that yielded unambiguous amplification products were selected for further analyses. Forward primers labeled with FAM, HEX, or TET (ABI, Foster City, CA; MWG Biotech, High Point, NC) were then used to collect genotypes for 95 individuals from five locations (Table I). DNA from individuals was amplified and electrophoresed as described for fluorescent dNTP amplifications, with only slight modifications to some annealing temperatures. Genotypes were determined using Genescan (ver. 3.2.1) and Genotyper (ver. 2.5) software (Applied Biosystems, Foster City, CA).

Departures from Hardy-Weinberg proportions and linkage disequilibrium between pairs of loci were tested using Fisher's exact test in the Genetic Data Analysis program (GDA; Lewis and Zaykin, 1999). Average numbers of alleles per locus, unique alleles, expected $\left(H_{\mathrm{e}}\right)$ and observed $\left(H_{\mathrm{o}}\right)$ heterozygosities, genetic distances (Nei, 1978), and $F$ statistics (significance of which was based on $95 \%$ confidence intervals determined by bootstrapping across loci; Weir and Cockerham 1984) were also determined using GDA. Allele frequencies for each locus and population were determined in Genepop (v3.2a; Raymond and Rousset, 1995) and allele frequency differences between population pairs were tested using Fisher's exact test. Significance of multiple pairwise comparisons was corrected using a sequential Bonferroni adjustment (Rice, 1989). Probabilities of exclusion and polymorphism information content (PIC) values were determined using Cervus (Marshall et al., 1998), although our sample sizes were insufficient for analysis of null alleles with that software. 


\section{RESULTS}

Six of 10 loci were useful, including 1 (Qm37) that had been reported previously as not amplifying red-winged blackbird DNA (Hughes et al., 1998). Over all samples, the number of alleles per locus ranged from $7(\mathrm{Qm} 21)$ to 19 (Mau20). The average number of alleles was 8.2 and the average expected heterozygosity $\left(\mathrm{H}_{e}\right)$ was 0.774 . Significant departures from Hardy-Weinberg proportions were detected only at Mau20 in birds from Alberta, Manitoba, and Minnesota. No overall evidence for genetic linkage of loci was detected. Allele frequencies by collection site, average number of alleles per locus, multilocus heterozygosity, and probability of exclusion are provided in Tables II and III. Unique alleles were detected at low $(<0.10)$ frequencies in all populations and a single population (Manitoba) possessed a unique allele at a frequency of 0.12 (Table II). Multilocus probabilities of exclusion for the first parent ranged from 0.944 to 0.977 (Table III), and indicate these loci would be useful in establishing familial relationships. Multilocus PIC values assessed over all populations ranged from 0.703 to 0.748 . Qm21 was consistently the least informative locus and Mau20 was the most informative.

Nei's (1978) genetic distances between population pairs were small (Table IV). Pairwise comparisons revealed significant overall allele frequency differences between California and Louisiana, Louisiana and Minnesota, and Alberta and both Louisiana and California. However, single locus $F_{\text {st }}$ values among populations were all less than 0.02 and the multilocus $F_{\text {st }}$ among populations, although significant, was also small (0.009), indicating that little of the genetic variation was partitioned among populations. Only two pairwise multilocus $F_{\mathrm{st}}$ values (between Minnesota and both California and Louisiana) were significant, but they too were small (Table IV). Although larger overall heterozygote deficiencies correspond to birds collected over larger geographic areas (Alberta, $F_{\text {is }}=0.13$, Minnesota, $F_{\text {is }}=0.10 ;$ Manitoba, $\left.F_{\text {is }}=0.07\right)$ than those from much smaller geographic areas (California, $F_{\text {is }}=0.02$; Louisiana, $F_{\text {is }}=0.03$ ), the lack of deviations from HardyWeinberg expectations indicated that none of the samples were from admixed populations. Overall, slight heterozygote deficiencies were observed within and among populations $\left(F_{\mathrm{is}}=0.07, F_{\mathrm{it}}=0.08\right)$, but they were not significant. Finally, although more significant pairwise allele frequency differences were detected between subspecies than within one subspecies, pairwise $F_{\text {st }}$ values between subspecies were no greater than those within subspecies.

\section{DISCUSSION}

We identified six microsatellite loci that are polymorphic in red-winged blackbirds, and we present allele size ranges and estimates of allele frequencies in putative populations from across North America. Low levels of genetic structuring among populations in this initial microsatellite survey may reflect either relatively recent 
Table II. Microsatellite Allele Frequencies for Red-Winged Blackbird Populations ${ }^{a}$

\begin{tabular}{|c|c|c|c|c|c|c|c|c|c|c|c|}
\hline & \multicolumn{5}{|c|}{ Population } & & \multicolumn{5}{|c|}{ Population } \\
\hline & $\mathrm{CA}$ & LA & $\mathrm{AB}$ & $\mathrm{MN}$ & MB & & $\mathrm{CA}$ & LA & $\mathrm{AB}$ & $\mathrm{MN}$ & MB \\
\hline Qm10 & & & & & & 161 & 0.08 & 0.28 & 0.15 & 0.30 & 0.11 \\
\hline 215 & 0.03 & 0.03 & 0.03 & 0.00 & 0.04 & 163 & 0.38 & 0.20 & 0.18 & 0.17 & 0.21 \\
\hline 218 & 0.05 & 0.00 & 0.03 & 0.04 & 0.00 & 165 & 0.03 & 0.10 & 0.05 & 0.03 & 0.07 \\
\hline 221 & 0.00 & 0.07 & 0.08 & 0.04 & 0.11 & 167 & 0.03 & 0.03 & 0.03 & 0.00 & 0.21 \\
\hline 224 & 0.18 & 0.17 & 0.03 & 0.19 & 0.21 & 169 & 0.05 & 0.03 & 0.15 & 0.03 & 0.00 \\
\hline 227 & 0.13 & 0.17 & 0.08 & 0.04 & 0.04 & 171 & 0.00 & 0.05 & 0.03 & 0.00 & 0.04 \\
\hline 230 & 0.13 & 0.23 & 0.20 & 0.04 & 0.14 & 177 & 0.03 & 0.00 & 0.00 & 0.00 & 0.04 \\
\hline 233 & 0.24 & 0.20 & 0.25 & 0.35 & 0.25 & Mau20 & & & & & \\
\hline 236 & 0.05 & 0.00 & 0.15 & 0.19 & 0.04 & 99 & 0.13 & 0.05 & 0.05 & 0.04 & 0.07 \\
\hline 239 & 0.03 & 0.00 & 0.10 & 0.08 & 0.07 & 103 & 0.00 & 0.00 & 0.00 & $0.07 *$ & 0.00 \\
\hline 242 & 0.16 & 0.10 & 0.03 & 0.00 & 0.07 & 107 & 0.00 & 0.08 & 0.03 & 0.00 & 0.04 \\
\hline 245 & 0.00 & 0.03 & 0.03 & 0.04 & 0.04 & 109 & 0.13 & 0.03 & 0.10 & 0.11 & 0.04 \\
\hline 248 & 0.00 & 0.00 & $0.03 *$ & 0.00 & 0.00 & 111 & 0.00 & 0.13 & 0.20 & 0.00 & 0.07 \\
\hline Qm21 & & & & & & 113 & 0.00 & 0.00 & 0.00 & $0.04 *$ & 0.00 \\
\hline 137 & 0.03 & 0.06 & 0.00 & 0.07 & 0.00 & 116 & 0.03 & 0.00 & 0.00 & 0.00 & 0.11 \\
\hline 140 & 0.08 & 0.03 & 0.00 & 0.00 & 0.03 & 118 & 0.05 & 0.05 & 0.05 & 0.11 & 0.00 \\
\hline 143 & 0.73 & 0.74 & 0.71 & 0.61 & 0.66 & 120 & 0.05 & 0.03 & 0.03 & 0.11 & 0.04 \\
\hline 146 & 0.08 & 0.12 & 0.19 & 0.14 & 0.22 & 122 & 0.13 & 0.00 & 0.03 & 0.00 & 0.11 \\
\hline 149 & 0.10 & 0.00 & 0.07 & 0.14 & 0.09 & 124 & 0.18 & 0.18 & 0.13 & 0.07 & 0.11 \\
\hline 152 & 0.00 & 0.06 & 0.00 & 0.04 & 0.00 & 126 & 0.08 & 0.13 & 0.10 & 0.11 & 0.11 \\
\hline 155 & 0.00 & 0.00 & $0.02 *$ & 0.00 & 0.00 & 128 & 0.08 & 0.13 & 0.05 & 0.21 & 0.07 \\
\hline Qm37 & & & & & & 130 & 0.00 & 0.08 & 0.08 & 0.04 & 0.04 \\
\hline 114 & 0.00 & 0.00 & $0.05^{*}$ & 0.00 & 0.00 & 132 & 0.03 & 0.11 & 0.08 & 0.00 & 0.07 \\
\hline 117 & 0.15 & 0.21 & 0.24 & 0.29 & 0.10 & 134 & 0.15 & 0.00 & 0.03 & 0.07 & 0.11 \\
\hline 120 & 0.15 & 0.05 & 0.10 & 0.25 & 0.03 & 136 & 0.00 & 0.00 & 0.05 & 0.00 & 0.04 \\
\hline 123 & 0.10 & 0.00 & 0.10 & 0.07 & 0.10 & 143 & 0.00 & 0.00 & $0.03^{*}$ & 0.00 & 0.00 \\
\hline 126 & 0.25 & 0.55 & 0.31 & 0.36 & 0.40 & 149 & 0.00 & 0.00 & 0.00 & $0.04 *$ & 0.00 \\
\hline 129 & 0.08 & 0.03 & 0.12 & 0.00 & 0.13 & Mau23 & & & & & \\
\hline 132 & 0.08 & 0.11 & 0.02 & 0.00 & 0.10 & 151 & 0.00 & 0.00 & 0.00 & 0.00 & $0.04 *$ \\
\hline 135 & 0.13 & 0.05 & 0.05 & 0.04 & 0.10 & 153 & 0.00 & 0.00 & 0.00 & 0.00 & $0.12^{*}$ \\
\hline 140 & 0.00 & 0.00 & $0.02 *$ & 0.00 & 0.00 & 157 & 0.03 & 0.03 & 0.00 & 0.04 & 0.00 \\
\hline 153 & 0.03 & 0.00 & 0.00 & 0.00 & 0.03 & 159 & 0.13 & 0.14 & 0.13 & 0.14 & 0.08 \\
\hline 156 & $0.03 *$ & 0.00 & 0.00 & 0.00 & 0.00 & 161 & 0.15 & 0.06 & 0.34 & 0.29 & 0.23 \\
\hline 159 & $0.03 *$ & 0.00 & 0.00 & 0.00 & 0.00 & 163 & 0.33 & 0.25 & 0.38 & 0.43 & 0.35 \\
\hline Mau10 & & & & & & 165 & 0.08 & 0.19 & 0.13 & 0.11 & 0.15 \\
\hline 153 & 0.03 & 0.05 & 0.05 & 0.00 & 0.04 & 167 & 0.23 & 0.19 & 0.03 & 0.00 & 0.00 \\
\hline 155 & 0.00 & 0.00 & 0.00 & $0.03 *$ & 0.00 & 169 & 0.08 & 0.08 & 0.00 & 0.00 & 0.00 \\
\hline 157 & 0.05 & 0.00 & 0.00 & 0.03 & 0.00 & 171 & 0.00 & $0.06^{*}$ & 0.00 & 0.00 & 0.00 \\
\hline 158 & 0.00 & 0.03 & 0.00 & 0.03 & 0.00 & 173 & 0.00 & 0.00 & 0.00 & 0.00 & $0.04 *$ \\
\hline 159 & 0.35 & 0.25 & 0.38 & 0.37 & 0.29 & & & & & & \\
\hline
\end{tabular}

${ }^{a} \mathrm{CA}$ - California; LA - Louisiana; AB - Alberta; MB - Manitoba; MN - Minnesota. Allele sizes in base pairs are under locus names. Unique alleles are indicated with an asterisk. 
Table III. Measures of Genetic Variability for Red-Winged Blackbirds

\begin{tabular}{|c|c|c|c|c|}
\hline \multirow[b]{2}{*}{ Population } & \multirow{2}{*}{$\begin{array}{l}\text { Average number of } \\
\text { alleles per locus }\end{array}$} & \multicolumn{2}{|c|}{ Multilocus heterozygosity } & \multirow{2}{*}{$\begin{array}{l}\text { Probability } \\
\text { of exclusion }\end{array}$} \\
\hline & & Expected & Observed & \\
\hline California & 8.5 & 0.78 & 0.77 & 0.97 \\
\hline Louisiana & 7.8 & 0.76 & 0.74 & 0.96 \\
\hline Alberta & 8.8 & 0.77 & 0.67 & 0.97 \\
\hline Minnesota & 7.3 & 0.77 & 0.69 & 0.94 \\
\hline Manitoba & 8.5 & 0.80 & 0.75 & 0.98 \\
\hline
\end{tabular}

range expansion from a common source, current levels of gene flow sufficiently high to limit genetic differentiation among populations, or both. Indeed, although most red-winged blackbirds exhibit nest site fidelity, those that do not may disperse tremendous distances (Dolbeer, 1978).

This suite of microsatellite loci will be of use to researchers examining relatedness among individual red-winged blackbirds, and could provide a valuable tool for studies examining reproductive behavior in this polygynous species. However, in an analysis using larger sample sizes, a high null allele frequency was detected at locus Mau20 in all five locations (0.09-0.28; not shown), indicating this locus is not suitable for analyses of relatedness in this species. Given that we detected some overall significant allele frequency differences between population pairs, larger sample sizes, and/or more loci may improve regional population resolution. We are currently analyzing much larger breeding season samples to better investigate the potential utility of these microsatellite loci. We acknowledge that detection of fine-scale local differentiation is unlikely, given that the allele frequency differences occur only between populations separated by vast distances. The high levels of variation (numbers of alleles/locus and heterozygosity) detected indicate red-winged-blackbird-specific loci are not likely to reveal greater levels of differentiation among breeding populations.

Table IV. Pairwise Genetic Distances and $F_{\text {st }}$ Values Between Red-Winged Blackbird Populations ${ }^{a}$

\begin{tabular}{lcccrr}
\hline & California & Louisiana & Alberta & Manitoba & Minnesota \\
\hline California & - & 0.016 & 0.011 & 0.002 & $0.015^{*}$ \\
Louisiana & 0.016 & - & 0.015 & 0.006 & $0.023^{*}$ \\
Alberta & 0.011 & 0.015 & - & -0.005 & -0.002 \\
Manitoba & 0.002 & 0.007 & -0.005 & - & 0.006 \\
Minnesota & 0.015 & 0.023 & -0.002 & 0.006 & - \\
\hline
\end{tabular}

${ }^{a}$ Genetic distances (Nei, 1978) are below the diagonal. $F_{\text {st }}$ values are above the diagonal. Significant values are indicated with an asterisk. Negative values are not different from 0. 


\section{ACKNOWLEDGMENTS}

We are grateful to W. J. Bleier, J. L. Cummings, P. Pochop, J. Schuler, A. Wilson, and R. L. Wimberley for assistance with sample collection, and Carol Furcolow and Dawn Reding for technical assistance. We thank two anonymous reviewers for their comments on an earlier version of this article.

\section{REFERENCES}

Ball, R. M., Jr., Freeman, S., James, F. C., Bermingham, E., and Avise J. C. (1988). Phylogeographic population structure of red-winged blackbirds assessed by mitochondrial DNA. Proc. Natl. Acad. Sci. U.S.A. 85:1558-1562.

Dolbeer, R. A. (1978). Movement and migration patterns of red-winged blackbirds: A continental overview. Bird Band. 49:17-34.

Gavin, T. A., Howard, R. A., and May, B. (1991). Allozyme variation among breeding populations of red-winged blackbirds: The California conundrum. The Auk 108:602-611.

Gibbs, H. L., Miller, P., Alderson, G., and Sealy, S. G. (1997). Genetic analysis of brown-headed cowbirds Molothrus ater raised by different hosts: Data from mtDNA and microsatellite markers. Mol. Ecol. 6:189-193.

Hughes, C. R., Kavlie, R., and Johnson, K. (1998). Characterization of polymorphic trinucleotide microsatellite loci in the great-tailed grackle, Quiscalus mexicanus. Mol. Ecol. 7:783-784.

James, F. C., Engstrom, R. T., and Nesmith, C. (1984). Inferences about population movements of red-winged blackbirds from morphological data. Am. Midl. Nat. 111:319-331.

Kroodsma, D. E., and James, F. C. (1994). Song variation within and among populations of red-winged blackbirds. Wilson Bull. 106:156-162.

Lewis, P. O., and Zaykin, D. (1999). Genetic data analysis: Software for the analysis of discrete genetic data. Version 1d16c. Available at http://lewis.eeb.uconn.edu/lewishome/gda.html.

Linz, G. M., Linz, L. J., Thompson, J. M., and Bleier, W. J. (1993). Using geographic variation to predict breeding locales of migrating red-winged blackbirds. Prairie Nat. 25:127-133.

Linz, G. M., Schaaf, D. A., Wimberly, R. L., Homan, H. J., Pugh, T. L., Peer, B. D., Mastrangelo, P., and Bleier, W. J. (2000). Efficacy and potential nontarget impacts of DRC-1339 avicide use in ripening sunflower fields: 1999 progress report. Proc. 22 Sunflower Res. Workshop 162-169.

Longmire, J. L., Lewis, A. K., Brown, N. C., Buckingham, J. M., Clark, L. M., Jones, M. D., Meincke, L. J., Meyne, J., Ratliff, R. L., Ray, F. A., Wagner, R. P., and Moyzis, R. K. (1988). Isolation and molecular characterization of a highly polymorphic centromeric tandem repeat in the family Falconidae. Genomics 2:14-24.

Marshall, T. C., Slate, J., Kruuk, L. E. B., and Pemberton J. M. (1998). Statistical confidence for likelihood-based paternity inference in natural populations. Mol. Ecol. 7:639-655.

Nei, M. (1978). Estimation of average heterozygosity and genetic distance from a small number of individuals. Genetics 3:489-495.

Peer, B. D., Homan, H. J., Linz, G. M., and Bleier, W. J. (2003). Impact of blackbird damage to sunflower: Bioenergetic and economic models. Ecol. Appl. 13:248-256.

Raymond, M., and Rousset, F. (1995). GENEPOP (v.1.2). A population genetics software for exact tests and ecumenicism. J. Hered. 86:248-249.

Rice, W. R. (1989). Analyzing tables of statistical tests. Evolution 43:223-225.

Weir, B. S., and Cockerham, C. C. (1984). Estimating $F$-statistics for the analysis of population structure. Evolution 38:1358-1370. 